\title{
A Research Note on the Relationship between Regulation and Audit Firm Size on Audit Fees
}

\author{
WILLIE E. GIST*
}

This study represents an initial attempt to examine some specific factors that might lead to large firms' economies of scale. Multiple regression analysis is used to test hypotheses concerning scale opportunities conferred on large CPA firms in dealing with regulatory complexity faced by the client. An analysis of interaction between audit firm size and variables measuring client regulatory complexity shows that audit fees are lower for all firms in regulated industries compared to nonregulated industries-the difference being much greater, however, for Big Eight (now Big Six) firms, and audit fees charged by Big Eight firms are much lower when the auditor is involved with client security registrations. This relationship does not hold true for non-Big Eight firms involved with client registration statements. Based on these results, it appears that client regulatory complexity confers greater scale opportunities to larger audit firms compared to smaller ones.

Several studies $[1,2,3]$ examining auditor concentration in the U.S. audit market have provided evidence that substantial economies of scale exist for the CPA firm in dealing with the regulatory complexity faced by clients. These studies, however, did not directly examine production costs or audit fees. If economies of scale do exist, and assuming that relative production costs are reflected in the external audit fee, then audit fees charged by firms are expected to be lower in a regulated environment compared to a nonregulated one. The present study examines the effect of variables proxying for regulatory aspects of the client on external audit fees.

As has been suggested by the Commission on Auditors' Responsibilities [4] and Arnett and Danos [5], it can be argued that substantial economies of scale exist for the CPA firms in dealing with the regulatory complexity faced by clients. For example, to issue an opinion on a client's $10-\mathrm{K}$ filing

*Assistant Professor, School of Accounting, University of Oklahoma 
with the SEC, a CPA firm must make substantial investments in human capital (expertise) related to SEC disclosure and measurement rules. Once this expertise has been acquired, additional clients subject to SEC filings can be serviced at lower marginal cost than the cost to service the first (or first few) such clients. Similar scale effects can be expected to occur within the contexts of clients issuing new publicly traded securities (capital market activity) and complying with industry-specific regulation.

Eichenseher and Danos [3] developed a model that explains the level of auditor concentration in any given industry. The model shows that the level of auditor concentration is significantly and positively related to the degree of client-industry regulation and capital market activity. They attributed this finding to scale effects. Although this finding is interesting, an equally interesting and related question is whether these scale effects are passed on to the auditee in the form of a lower audit fee or do CPA firms actually operate as a cartel (taking advantage of their concentrated position).

Danos and Eichenseher $[1,2]$, in studying changes in seller concentration in the U.S. audit market over time, provided results consistent with the previous finding concerning possible scale effects in regulated industries. More specifically, in the 1982 study, larger CPA firms appeared to gain market shares overall; but in "nonregulated" industries, large industryspecific market shares tended to erode. Such erosion was not observed in "regulated" industries. In the 1986 study, Danos and Eichenseher concluded that for "regulated" client industries, evidence as to increasing competition among large CPA firms is lacking. Presumably, the scale opportunities in such environments confer competitive advantages on a small subset of large firms. The results of these studies suggest that the scale effects due to regulatory complexity are much greater for larger CPA firms.

The purpose of the present study is to extend the work of Danos and Eichenseher $[1,2,3]$ by examining the interrelationship between variables proxying for regulatory complexity and audit firm size on external audit fees. An audit fee model will include constructs on the two sources of mentioned regulatory complexity; that is, it is posited that greater scale opportunities exist with increased auditor involvement in the security registration process (capital market activity) and in servicing clients in regulated industries. This study is important because it represents an initial attempt to consider factors other than firm size that may confer competitive advantages to CPA firms. ' It is also important to understand how these factors-

1. According to Benston [11], large accounting firms have the standardized audit methodology, staff size, and multiple-office locations to efficiently conduct audits of large companies. Small firms, on the other hand, are inefficient producers of such audits because of the need to develop more audit specific (rather than standardized) audit methodology, and extensive traveling or subcontracting with 
client regulation and capital market activity, which are typically beyond the control of CPA firms-moderate in the relationship between audit firm size and audit fees. Further, the concerns of congressional critics about possible cartel pricing by larger CPA firms may be lessened if evidence is provided that scale effects accruing to these firms are being passed on to the auditee (consumer) in the form of a lower audit fee.

The expectation is that the magnitude of the effect of audit firm size on audit fees is affected by or depends on the regulatory complexity of the client. A test of this requires an analysis of interaction effects, which has not been done previously in the literature. The primary hypotheses stated in alternate form are as follows:

$H_{1}$ : There is a significant and positive interaction effect between variables measuring audit firm size and client capital market activity on external audit fees.

$\mathrm{H}_{2}$ : There is a significant and positive interaction effect between variables measuring audit firm size and client industry membership on external audit fees.

\section{Research Design and Sample Selection}

The audit fee regression model used to test the hypotheses is basically Simunic's [6] and has stood the test of time. Therefore, it is not necessary to provide justification for the inclusion of his variables. Table 1 provides a summary of the variables used. Other studies using Simunic's basic model include Francis [7], Francis and Stokes [8], Palmrose [9], and Francis and Simon [10].

\subsection{Sample}

A stratified sample of 500 companies was contacted during 1987 through a questionnaire mailed to the controller or chief financial officer. The sample was stratified by asset size (companies with assets of less than $\$ 150$ million and those with assets greater than $\$ 150$ million) and by auditor group (Big

other auditors to deal with auditee size and multiple location problems. Also, complex accounting transactions and reporting requirements may require specialized auditor expertise. The costs of human capital investment required for these skill specializations can be spread over more audits thus creating scale economics. However, small firms face diseconomies of scale because these costs cannot be recouped over a large number of audits. 


\title{
TABLE 1
}

\section{Variable and Operational Proxies}

\author{
Independent Variables
}

\section{Control}

Variables

Definition

Assets

\section{Total year-end Assets of Auditee}

Subs Number of consolidated subsidiaries

FA Ratio of foreign assets to total assets at year-end

Internal audit activity as measured by the annual payroll of internal audit department/total assets

OP Type of audit opinion ( $1=$ unqualified and consistency exception, $0=$

"subject to" qualification)

ROI Retum on investment (net income or net loss/total assets)

DA Total long-term debt to total assets at year-end

MON Month of year-end $(1=$ non-12/31 year-end and $0=12 / 31$ year-end)
Test

Variables

Definition

Firm-B8

Big Eight auditor size indicator variable $(1=$ Big Eight firm and $0=$ non-Big Eight firm)

I

Industry regulatory complexity variable $(1=$ regulated and $0=$ nonregulated industry)

CM

Variable measuring the amount of capital market activity as measured by the number of debt and equity security registration forms (i.e., the number of

S-1's, S-2's, S-3's, and S-7's) filed annually pursuant to the 1933 SEC Act over the period of 1983-1985.

Firm-B8*I Firm by industry interaction term

Firm-B8*CM Firm by capital market activity interaction term

\section{Dependent \\ Variable \\ Definition}

FEE

The total annual audit fee paid to the external auditor 
Eight ${ }^{2}$ firms versus non-Big Eight firms). Five regulated industries and five nonregulated industries are represented in the sample. ${ }^{3}$ However, as discussed later strong inferences cannot be drawn for individual industries due to the relatively small number of observations per industry. The one-page questionnaire consisted of items on audit fees, security registration, internal audit activity, the number of physical operating locations visited by the external auditor, and the number of consolidated subsidiaries, which were not available from public data sources such as the annual report and editions of Who Audits America [13]. ${ }^{4}$

Three years (1983-1985) of data were requested on each auditee. One hundred seven companies responded for a 21 percent response rate. ${ }^{5} \mathrm{Ob}$ servations for 12 companies in the sample were not usable due to the audit fee not being separable from other fees paid to the external auditor and/or incomplete data items. ${ }^{6}$

Two hundred and sixty-three responses were obtained from the 95 companies retained in the sample. A few companies indicated that some of the data were not available for earlier years. Descriptive statistics by auditor size are provided in Table 2. As shown in Table 2, Big Eight auditors audit larger and more complex companies than non-Big Eight auditors. The audit fee model does control for these cross-sectional differences.

A standard test of nonrespondent biases [15] was performed. The mean values of most of the variables reported by early and late respondents were

2. The Big Eight auditors were Arthur Andersen, Arthur Young, Coopers and Lybrand, Deloitte Haskins and Sells, Ernst and Whinney, Peat Marwick Mitchell, Price Waterhouse, and Touche Ross. Since the collection of data for this study in 1987, Arthur Andersen and Arthur Young merged; and, Deloitte Haskins and Sells and Touche Ross merged. These firms are currently referred to as the Big Six instead of the Big Eight.

3. Standard and Poor's Register of Corporations, Directors, and Executives [12] and Who Audits America [13] were used as the data sources. Four strata were used. Two hundred and ninety companies with a Big Eight auditor were selected. One hundred and seventy-eight of these had assets greater than $\$ 150$ million and the other 112 had assets less than $\$ 150$ million. And, 210 companies with a non-Big Eight auditor were selected. One hundred and seventy-five were classified as small auditees and $\mathbf{3 0}$ were classified as large auditees. Regulated industries included in the sample were Trucking, Telecommunication, Gas and Electric Utilities, Savings and Loan, and Insurance. Nonregulated industries included were Oil and Gas, Steel, Office Equipment, Retail Grocery, and Hotel and Motel. The regulation captured is conditioned on its effect on formal accounting reports and the underlying audit process. Therefore, the assignment of companies to regulated/nonregulated categories based on the SIC code may be an oversimplification given the nature of this study.

4. The questionnaire also requested items such as tax and management advisory services to ensure that these items were not included in the external audit fee. An item relating to the ownership of stock by officers and directors was also included, although these data are not used in the present study. Copies of the questionnaire are available on request.

5. Sixty-seven of the 107 companies responding had a Big Eight auditor, and the remaining 40 companies had a non-Big Eight auditor.

6. Five of the 12 companies changed auditors during the sample period. There were only 2 companies in the usable sample that changed auditors. The results of the tests were not changed when excluding these 2 companies from the analysis or when using an indicator variable to control for auditor changes. See De Angelo [14] for a discussion of low balling. 


\section{TABLE 2}

\section{Descriptive Statistics by Auditor Size}

\begin{tabular}{|c|c|c|c|}
\hline & & $\begin{array}{l}160 \text { Observations on } \\
\text { Auditees Using a } \\
\text { Big Eight Auditor }\end{array}$ & $\begin{array}{l}103 \text { Observations on } \\
\text { Auditees Using a } \\
\text { Non-Big Eight Auditor }\end{array}$ \\
\hline Fee: & $\begin{array}{l}\text { Mean } \\
\text { S.D. }\end{array}$ & $\begin{array}{l}\$ 304.0 t \\
(422.0 t)\end{array}$ & $\begin{array}{l}\$ 56.4 t \\
(59.0 t)\end{array}$ \\
\hline Assets: & $\begin{array}{l}\text { Mean } \\
\text { S.D. }\end{array}$ & $\begin{array}{l}\$ 2,849.3 \mathrm{~m} \\
(4,897.1 \mathrm{~m})\end{array}$ & $\begin{array}{l}\$ 109.0 \mathrm{~m} \\
(222.2 \mathrm{~m})\end{array}$ \\
\hline AudL: & $\begin{array}{l}\text { Mean } \\
\text { S.D. }\end{array}$ & $\begin{array}{c}5.4 \\
(6.4)\end{array}$ & $\begin{array}{c}1.7 \\
(1.1)\end{array}$ \\
\hline Subs: & $\begin{array}{l}\text { Mean } \\
\text { S.D. }\end{array}$ & $\begin{array}{c}15.1 \\
(32.8)\end{array}$ & $\begin{array}{l}2.3 \\
(2.9)\end{array}$ \\
\hline FA: & $\begin{array}{l}\text { Mean } \\
\text { S.D. }\end{array}$ & $\begin{array}{l}1.7 \% \\
(5.5)\end{array}$ & $\begin{array}{l}.1 \% \\
(.7)\end{array}$ \\
\hline ROI: & $\begin{array}{l}\text { Mean } \\
\text { S.D. }\end{array}$ & $\begin{array}{l}3.5 \% \\
(6.1)\end{array}$ & $\begin{array}{l}-2.3 \% \\
(19.7)\end{array}$ \\
\hline DA: & $\begin{array}{l}\text { Mean } \\
\text { S.D. }\end{array}$ & $\begin{array}{l}26.1 \% \\
(18.8)\end{array}$ & $\begin{array}{l}16.9 \% \\
(19.5)\end{array}$ \\
\hline IAA: & $\begin{array}{l}\text { Mean } \\
\text { S.D. }\end{array}$ & $\begin{array}{l}.5 \% \\
(3.8)\end{array}$ & $\begin{array}{l}.0038 \% \\
(.0173)\end{array}$ \\
\hline CM: & $\begin{array}{l}\text { Mean } \\
\text { S.D. }\end{array}$ & $\begin{array}{c}1.5 \\
(2.4)\end{array}$ & $\begin{array}{l}.29 \\
(.65)\end{array}$ \\
\hline \multicolumn{2}{|c|}{$\begin{array}{l}\text { Percentage of observations } \\
\text { in regulated industries }\end{array}$} & $60.6 \%$ & $43.7 \%$ \\
\hline \multicolumn{2}{|c|}{$\begin{array}{l}\text { Percentage of observations } \\
\text { with } 12 / 31 \text { year-end }\end{array}$} & $90.0 \%$ & $65.0 \%$ \\
\hline \multicolumn{2}{|c|}{$\begin{array}{l}\text { Percentage of observations } \\
\text { with "subject to" } \\
\text { opinion }\end{array}$} & $7.5 \%$ & $8.7 \%$ \\
\hline
\end{tabular}

not significantly different at $P$-value $=.10{ }^{7}$ However, the test of nonresponse bias seems to indicate a reluctance of companies in the sample with non-Big Eight auditors to respond on the first request for audit fee information. Only 28 percent of early responses were from companies with non-

7. The first request for audit fee data was mailed to companies in the sample April 10, 1987, followed by a second request mailed five weeks from that date. Those companies responding by the mailing of the second request were classified as early respondents. One hundred and twenty-three observations were received from 44 early respondents, and 140 observations were received from 51 late respondents. 
Big Eight auditors. Forty-nine percent of second requests represent companies with non-Big Eight auditors. This finding is consistent with the lower mean fee and assets of the late respondents. Fee and assets were significantly different among the early and late respondents at $P$-value $=.07$. This result is expected because companies with non-Big Eight auditors tend to be smaller in size and require less audit services from external auditors than larger companies. However, I cannot explain how the results would be affected in the absence of this nonresponse bias. Simunic [6] also reported a reluctance of companies using non-Big Eight auditors to respond to his survey.

\subsection{Capital Market Activity}

Eichenseher and Danos [3] posited that production economies of scale exist, in general, in the context of specialization. The effects of such specialization become embedded in the firm to the extent that competitive markets for specialized products or services fail to evolve. They argued that greater scale opportunities exist in industries where companies are relatively more active in issuing new publicly traded securities. The fact that large CPA firms provide advanced in-house training courses related to SEC registration is indirect support for this assumption. A CPA firm making a substantial investment in expertise related to SEC disclosure and measurement rules may service additional clients subject to SEC filings at a lower marginal cost than the cost to service the first such clients, once this expertise has been acquired. Eichenseher and Danos showed that the importance of new security issuances in a particular industry was positively related to the degree of auditor concentration. The importance of new security issuances was defined as the number of registration statements filed with the SEC by industry members, divided by the number of firms assigned to the industry SIC code by the SEC. The results supported their expectation that higher concentration levels would be expected in those industries where more pronounced economies of scale exist for the CPA firm.

Assuming that relative production cost is reflected in external audit fees, then the effects of specialization and accompanying production scale economies relating to new security registration should result in lower fees. The present study attempts to measure the spillover effect of specialized knowledge acquired in the registration process on the recurring annual audit. Thus, the annual audit fee requested in this study does not include the fee associated with the auditor's involvement with the registration statements. The number of debt and equity security registration statements filed with the SEC (referred to as the capital market activity variable-CM) by each auditee is used in this study. Based on the preceding discussion, the expectation is 
that audit fees are lower for those auditees with greater involvement by the auditor in the security registration process. ${ }^{8}$ Further, these scale effects are much greater for larger CPA firms compared to smaller CPA firms. The alternative hypothesis was stated previously as hypothesis 1 .

\subsection{Industry Regulatory Complexity}

Eichenseher and Danos [3] also posited that production economies of scale exist in the servicing of clients in "regulated" industries. This position was based on the effects of specialization discussed previously. They found auditor concentration to be a positive function of the degree of client-industry regulation. A binary variable was used to indicate whether a particular industry was subject to regulation that impacted directly on the construction of its members' financial statements. As noted by Eichenseher and Danos the regulation captured by this variable is conditioned only on its effect on formal accounting reports and the underlying audit process, as almost all industries in the U.S. economy are "regulated" to some extent in the sense that governmental bodies place constraints on their actions.

If concentration is explained by increasing production economies of scale due to industry regulatory complexity and relative production cost is reflected in external audit fees, then one would expect audit fees to be lower in regulated industries compared to nonregulated industries. The present study tests this hypothesis using the industry regulatory complexity (I) indicator variable. Also, as an alternative, a separate indicator variable for each particular industry is used because audit pricing may differ quite dramatically even across regulated industries because of the different types and scopes of regulations. ${ }^{9}$ However, the coefficients for the individual industry variables are not meaningful and strong inferences cannot be drawn due to the relatively small number of observations per industry.

The scale effects due to industry regulatory complexity are expected to be much greater for larger CPA firms compared to smaller CPA firms. The alternate hypothesis was stated previously as hypothesis 2 .

8. There could be cross-subsidies in that audit fees might be lower in the presence of greater values of $\mathrm{CM}$ because some of the audit work may be implicitly allocated to this work. This effect may also be related to the CPA's desire to keep a growth or prestige client through discounted prices.

9. Simunic's [6] sample was sensitive to industry effects. A separate dummy variable for banks was significant in his study and banks were eventually dropped because they produced residual outliers, and were all audited by Big Eight firms. Francis [7] also reported a significant dummy variable for financial institutions and dropped those observations to produce a more homogeneous sample. The inclusion of financial institutions in other studies (for example [9]) did not appear to create a problem. Dummy variables for savings and loans and insurance companies were not significant in the present study. Nevertheless, the results of this study are substantially unchanged when these financial institutions are excluded. The coefficients for Trucking and Telecommunication are negative and significant at the .10 and .01 levels, respectively. The coefficient for utilities is also negative but not significant. 


\section{Results}

The effect of the relationship between firm size and client regulation on audit fees is not tested in the large auditee subsample since the firm size variable is not significant $(P$-value $=.985){ }^{10}$ The emphasis of this study is that of examining the interaction effect of firm size, when it is significant, with variables measuring the degree of client-industry regulatory complexity or the amount of client capital market activity.

The multiple regression models with the interaction effects for the small auditee subsample are presented in Table $3 .{ }^{11}$ The firm size variable is positive and significant (at $P$-value $=.067$ ), indicating that the Big Eight firms charge a premium over non-Big Eight firms in this small auditee subsample. This result is consistent with a Big Eight audit fee premium being observed in other studies $[9,10]$ of small auditee subsamples of the U.S. audit market.

The industry regulatory complexity variable (I) is negative and significant (at the .018 level) as hypothesized, which indicates that audit fees are lower in regulated industries. However, the capital market activity variable $(\mathrm{CM})$ is not significant $(P$-value $=.719)$, which may be explained by the small number of security registration statements filed by small auditees. ${ }^{12}$

10. The audit fee model for the large auditee subsample is not presented. Nevertheless, no audit fee difference among the Big Eight and non-Big Eight firms is consistent with other studies $[6,9]$ of large auditee subsamples in the U.S. audit market. The industry variable (I) is also not significant $(P$ value $=.344)$. Whereas, the capital market activity variable $(C M)$ is significant $(P$-value $=.023)$ and in the hypothesized direction (negative)

11. A null hypothesis that the residuals are normally distributed cannot be rejected at the .05 level for the sample, before or after transformation, using a Smimov test. An inspection of the residual plots, however, indicates a more normal distribution about the mean after transformation of the data. A Goldfeld-Quandt test [16] is used to test for violation of the constant variance assumption. The nul] hypothesis of homoscedasticity cannot be rejected at the .05 level for the model with the transformed data. This hypothesis, however, is rejected at the .05 level when the data are not transformed. Thus, the transformation procedure resulted in the equal variance assumption being met. In the GoldfeldQuandt test, regression models are run on an upper and lower percent of the sample based on the predicted values of the dependent variable. A central number of observations are omitted. The null hypothesis is that the sum of squared errors for the upper and lower percentage of the sample are equal. The central 20 percent of the observations were dropped for this test.

12. As reported in footnote 10 , the $\mathrm{CM}$ variable is significant in the large auditee subsample. Companies in the large auditee subsample filed more statements on average (mean $=1.9$ and standard deviation of 2.5) than companies in the small auditee subsample (mean $=0.2$ and standard deviation of 0.5 ). The number of statements filed ranged from 0 to 15 for the large auditee subsample, and from 0 to 4 for the small auditee subsample. This is not inconsistent with larger companies requiring more capital for their level of operations and acquires the necessary financial capital through public offerings. The correlation between CM and Assets is .678, which is moderately high as expected. However, an examination of the variance inflation factors (VIF) did not reveal any collinearity problems. According to Neter et al. [17], a VIF of 10 or more is a sign that multicollinearity may be a serious problem. The square root of assets has the highest VIF factor at 2.33. Therefore, the conclusion is that multicollinearity is not a problem of this study. As a matter of fact, the correlation between assets and $\mathrm{CM}$ is much higher than that between any other independent variables. 


\section{TABLE 3}

\section{Regression Models with Interaction Effect Big 8 Versus Non-Big 8 in the Small Auditee Sample (139 Observations with Assets $\leq \$ 150 \mathrm{~m}$ )}

Firm by Industry Interaction
Firm by Capital Market Activity Interaction

Dependent variable: LFee

\begin{tabular}{|c|c|c|c|c|c|c|c|c|}
\hline \multirow{2}{*}{$\begin{array}{c}\text { Independent } \\
\text { Variables }\end{array}$} & \multicolumn{3}{|c|}{ Standard } & \multicolumn{5}{|c|}{ Standard } \\
\hline & Coefficient & Error & F Statistic & P-Value & Coefficient & Error & F Statistic & P-Value \\
\hline RAssets & 0.0071 & 0.0005 & 386.85 & 0.001 & 0.0071 & 0.0005 & 390.26 & 0.001 \\
\hline RSubs & 0.0517 & 0.0656 & 8.01 & 0.005 & 0.0207 & 0.0671 & 8.08 & 0.005 \\
\hline FA & 0.0054 & 0.0126 & 1.07 & 0.303 & 0.0055 & 0.0125 & 1.08 & 0.301 \\
\hline ROI & -0.1784 & 0.2667 & 1.02 & 0.315 & -0.2099 & 0.2651 & 1.03 & 0.312 \\
\hline DA & 0.1934 & 0.2247 & 1.23 & 0.269 & 0.1766 & 0.2235 & 1.24 & 0.267 \\
\hline RIAA & -0.3407 & 0.6103 & 0.01 & 0.921 & -0.3779 & 0.6059 & 0.01 & 0.919 \\
\hline CM & -0.0244 & 0.0284 & 0.13 & 0.719 & 0.1824 & 0.0984 & 0.13 & 0.718 \\
\hline OP & -0.0644 & 0.1717 & 0.08 & 0.774 & -0.1115 & 0.1713 & 0.08 & 0.773 \\
\hline 0 & 0 & & & & 0 & & & \\
\hline 1 & -0.2872 & 0.1173 & 5.75 & 0.018 & -0.1482 & 0.0961 & 5.81 & 0.017 \\
\hline 0 & 0 & & & & 0 & & & \\
\hline MON1 & 0.3069 & 0.0891 & 11.24 & 0.001 & 0.2674 & 0.0882 & 11.34 & 0.001 \\
\hline 0 & 0 & & & & 0 & & & \\
\hline Firm-B8 & 0.0527 & 0.1147 & 3.41 & 0.067 & 0.2314 & 0.0974 & 3.44 & 0.066 \\
\hline Non B8 & 0 & & & & o & & & \\
\hline Firm-B8*I & 0.3408 & 0.1867 & 3.33 & 0.071 & - & & & \\
\hline Firm-B8*CM & - & & & & -0.2188 & 0.1035 & 4.47 & 0.036 \\
\hline Overall $F$-test & & 35.18 & & & & 35.58 & & \\
\hline$P$-value & & 0.001 & & & & 0.001 & & \\
\hline RSquare & & 0.77 & & & & 0.77 & & \\
\hline
\end{tabular}

\footnotetext{
When separate industry dummy variables are used the coefficients for Trucking and Telecommunications are negative and significant at the .10 and .01 levels, respectively. The coefficient for utilities is also negative but not significant. It should be noted that when separate industry variables are used the firm size variable becomes significant at the .01 level and the RSquare increases to .80 .

Coding:

LFee = natural log of audit fee.

RAssets = square root of total assets.

RSubs = square root of number of consolidated subsidiaries.

$\mathrm{FA}=$ total foreign assets $/$ total assets.

ROI $=$ net income (loss)/total assets.

$\mathrm{DA}=$ total long-term debt/total assets.

RIAA = square root of annual internal audit payroll/total assets.

CM = number of security registration forms filed.

$\mathrm{OP}=$ Opinion-1 for unqualified or consistency exception opinion or 0 for "subject to" qualification.

$I=$ Industry -1 for regulated industry or 0 for nonregulated industry.

MON $=$ Month-of-year end $=1$ for non-12/31 year end or 0 for 12/31 year end.

Firm = B8 for Big Eight or Non-B8 for non-Big Eight.

Firm-B8*I = firm by industry interaction effect.

Firm-B8*CM $=$ firm by capital market activity interaction effect.
} 
Empirical evidence is provided partly in support of hypothesis $1\left(H_{1}\right)$. The firm size by capital market activity interaction variable (Firm-B8*CM) is negative and significant $(P$-value $=.036)$. An explanation for the negative coefficient is provided in the following. A graphical presentation of the interaction effect is shown in Figure 1. Levels 1 and 2 of the CM variable represent no security registration statements filed, and one or more security registration statements filed, respectively. Whereas for the firm size variable, levels 1 and 2 represent the Big Eight and non-Big Eight firms, respectively. The graph does bear out and highlight the significance of this interaction effect.

The graph indicates that the fees charged by Big Eight auditors are much lower when the auditor is involved with client security registrations. The mean fee charged when Big Eight auditors are involved with security registrations is $\$ 56,333$, compared to a mean fee of $\$ 81,053$ when they are not involved. However, for the non-Big Eight auditors, the fee is higher when they are involved in the security registration process. The mean fee charged when non-Big Eight auditors are involved in the registration process is $\$ 49,000$, compared to a mean fee of $\$ 37,562$ when they are not involved. The different impact of the Big Eight and non-Big Eight involvement in the security registration process may reflect the volume of registration work by the Big Eight and their specialization as evidenced by the fact that they provide advanced in-house training courses related to SEC registration forms. Thus, this differential impact of the firms' involvement in the registration process resulted in the negative coefficient.

Figure 1 also provides data on intermediate and marginal cell means that were used to plot the firm by capital market activity interaction effect. The number indicated in parentheses is the frequency of observations in that cell. There were 111 observations on auditees not filing any statements and 28 observations on auditees filing one or more statements. The related mean audit fees for those filing no statements and those filing at least one are $\$ 52,450$ and $\$ 52,929$, respectively. The 53 observations on auditees with Big Eight auditors amount to a mean audit fee of $\$ 74,057$, whereas the mean audit fee for 86 observations on auditees with non-Big Eight auditors is $\$ 39,291$.

Empirical evidence is provided in support of hypothesis $2\left(\mathrm{H}_{2}\right)$. The firm size by industry interaction variable (Firm-B $8 * \mathrm{I})$ is positive and significant $(P$-value $=.071)$. A graphical presentation of the interaction effect is provided in Figure 2. As indicated in the graph, the relationship is very pronounced. The graph shows that audit fees charged by both Big Eight and non-Big Eight firms appear to be lower in regulated industries as compared to non-regulated industries. This relationship is even steeper for the 
FIGURE 1

Graph of Firm by Capital Market Activity Interaction Effect

\section{Mean Audit Fee per level of Interacting Variables}

Audit Fee (Thousands)

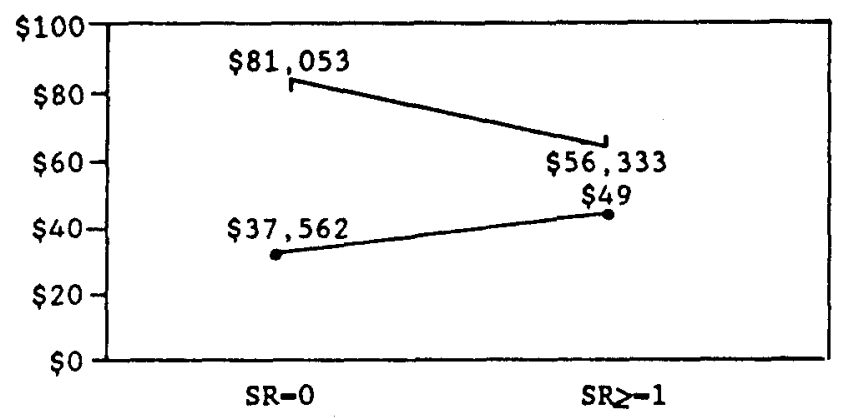

Capital Market Activity

$$
\text { Non-BIB } 8 \longrightarrow \text { Big } 8
$$

Intermediate and Marginal Cell Means

\section{Eirm Type}

$\begin{array}{cccc} & \text { Big } 8 & \text { Non-Big } 8 & \text { Totals } \\ S R=0 & \$ 81,053 & \$ 37,562 & \$ 52,450 \\ & (38) & (73) & (111)\end{array}$

SR Forms Filed

$\begin{array}{cccc}S R z-1 & \$ 56,333 & \$ 49,000 & \$ 52,929 \\ & (15) & (13) & (28) \\ \text { Totals } & \$ 74,057 & \$ 39,291 & \\ & (53) & (86) & \end{array}$

$S R$-the number of security registration forms filed, which is the measure of client capital market activity used in this study. 
FIGURE 2

Graph of Firm by Industry Interaction Effect

\section{Mean Audit Fee per level of Interacting Varlables}

Audit Fee (Thousands)

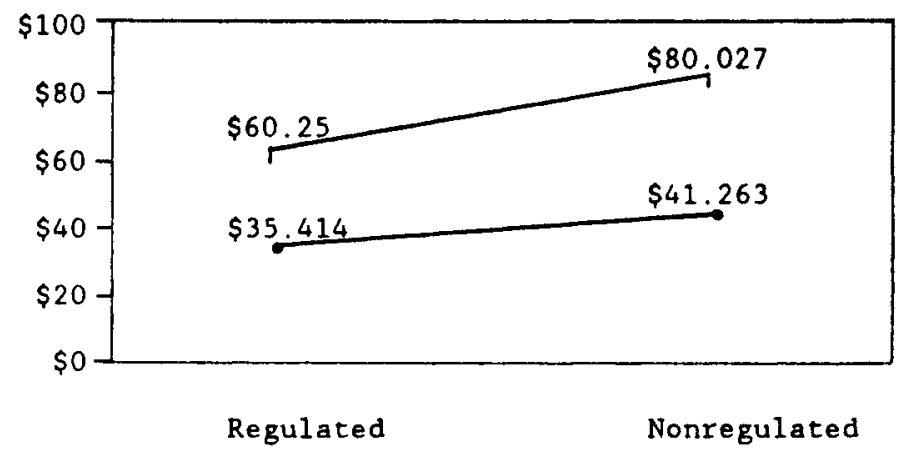

Industry

$$
\longrightarrow \text { Non-Big } 8 \longrightarrow \text { - } 1 \text { ig } 8
$$

Intermediate and Marginal Cell Means

\section{Firm Type}

Industry

$\begin{array}{cccc} & \text { Big } 8 & \text { Non-Big } 8 & \text { Totals } \\ \text { Regulated } & \$ 60,250 & \$ 35,414 & \$ 44,245 \\ & (16) & (29) & (45)\end{array}$

$\begin{array}{rccc}\text { Nonregulated } & \begin{array}{c}\$ 0,027 \\ (37)\end{array} & \$ 41,263 & (57) \\ \text { Totals } & \$ 74,057 & \$ 36,521 & (94) \\ & (53) & (86) & \end{array}$

Big Eight firms. The mean fee charged by Big Eight auditors in regulated industries is $\$ 60,250$, compared to $\$ 80,027$ in nonregulated industries. Although the mean fee charged by non-Big Eight auditors in regulated industries is $\$ 35,414$, compared to $\$ 41,263$ in nonregulated industries. 
Figure 2 also provides data on intermediate and marginal cell means that were used to plot the firm by industry interaction effect. The number indicated in parentheses is the frequency of observations in that cell. The mean audit fees in regulated and nonregulated industries are $\$ 44,245$ and $\$ 56,521$, respectively. The table also provides the frequency and mean audit fee for combinations of levels of each variable.

The results of tests performed in this section provide support for the hypothesis that the effect of audit firm size on audit fees is affected by or depends on the regulatory complexity of the client. This study provides evidence of significant interaction effects between audit firm size and clientindustry regulatory complexity and client capital market activity. The graphical analysis of the interaction effects provides more information and new insights on the underlying relationships. Prior audit fee research failed to consider these interactions. Also, this study is consistent with the work by Danos and Eichenseher $[1,2,3]$ concerning factors affecting changes in client-industry market shares. They provided evidence that client regulatory complexity confer scale opportunities to large CPA firms. The present study shows lower Big Eight audit fees in a regulated environment compared to a nonregulated one. Fees are even lower for non-Big Eight firms in regulated industries compared to nonregulated industries. Audit fees were not lower, however, for non-Big Eight firms involved with client security registration statements.

\section{Conclusion and Limitations}

This study examines the interacting relationship between audit firm size and variables proxying for client regulatory complexity to provide evidence on specific factors that might lead to large firms' economies of scale. Those factors relate to client industry membership and the amount of client capital market activity. These factors were hypothesized to be negatively related to external audit fees based on arguments concerning increasing production economies of scale in providing auditing services. The primary hypotheses were tested by examining the effect of audit firm size on audit fees while varying the degree of client regulatory complexity.

Evidence is provided in support of the primary hypotheses. More specifically, in a small auditee subsample, the results indicate lower audit fees for both Big Eight and non-Big Eight firms in regulated industries compared to nonregulated industries. However, the difference is greater among the Big Eight firms. Also, the results indicate that fees charged by the Big Eight firms are lower when these firms are involved with client security registra- 
tions. To the contrary, fees charged by the non-Big Eight firms are higher when they are involved with client security registrations. This result for the non-Big Eight firm involvement with security registrations is not consistent with the spillover of specialized knowledge acquired in the registration process to the recurring annual audit. However, the different impact of the Big Eight versus the non-Big Eight involvement in the security registration process may reflect the greater volume of registration work by the Big Eight and their specialization, as evidenced by the fact that they provide advanced in-house training courses related to SEC registration forms.

Based on the results of this study, it appears that client regulatory complexity confers greater scale opportunities to larger audit firms compared to smaller ones. These scale opportunities are passed on to the auditee in the form of a lower audit fee. Thus, the analysis of interaction effects between firm size and regulatory aspects of the client provides more information and new insights on underlying relationships.

It should be noted, however, that the present study does not attempt to examine factors, such as firm audit methodology, staff size, and multiple office locations, that may affect audit efficiency. Differences in these factors may even contribute to differential scale effects enjoyed among large accounting firms. This study basically represents an initial attempt to examine regulatory aspects of the client that might lead to large firms' economies of scale.

The results should be interpreted with caution because variables are weighted more heavily for some companies than others. Most companies did provide the three years of data requested. However, a few companies indicated the data were readily available only for the two most recent years. Also, it is important to note that the regulation captured in the industry regulatory complexity variable is conditioned only on its effect on formal accounting reports and the underlying audit process, because almost all industries in the U.S. economy are "regulated" to some extent in the sense that governmental bodies place constraints on their actions. Therefore, the assignment of companies to regulated/nonregulated categories based on the SIC code may be an oversimplification given the different types and scopes of regulations in these industries. Further, the capital market activity variable could be proxying for some residual industry effect (e.g., utilities have more capital market activity as defined by this study). Caution must also be taken when attempting to generalize the results of this sample to those of larger samples. Likewise, generalizations are limited because the ability to observe price differences among audit firms may be sensitive to the definition of auditee size. 


\section{REFERENCES}

1. P. Danos and J. Eichenseher. 1982. "Audit Industry Dynamics: Factors Affecting Changes in Client-Industry Market Shares." Journal of Accounting Research (Autumn): 604-616.

2. P. Danos and J. Eichenseher. 1986. "Long-Term Trends Toward Seller Concentration in the U.S. Audit Market." The Accounting Review (October): 633-50.

3. J. Eichenseher and P. Danos. 1981. "The Analysis of Industry Specific Auditor Concentration: Towards an Explanatory Model." The Accounting Review (July): 479-492.

4. American Institute of Certified Public Accountants (AICPA). 1978. The Commission on Auditors' Responsibilities, Report, Conclusions, and Recommendations. The Commission on Auditors' Responsibilities. New York: AICPA.

5. H. Arnett and P. Danos. 1979. CPA Firm Viability. University of Michigan.

6. D. Simunic. 1980. "The Pricing of Audit Services: Theory and Evidence." Journal of Accounting Research (Spring): 161-190.

7. J. Francis. 1984. "The Effect of Audit Firm Size on Audit Prices: A Study of the Australian Market." Journal of Accounting and Economics (March): 133-151.

8. J. Francis and D. Stokes. 1986. "Audit Prices, Product Differentiation and Scale Economies: Further Evidence from the Australian Market." Journal of Accounting Research (Autumn): 383393.

9. Zoe-Vonna Palmrose. 1986. "Audit Fees and Auditor Size: Further Evidence." Journal of Accounting Research (Spring): 97-110.

10. J. Francis and D. Simon. 1987. "A Test of Audit Pricing in the Small-Client Segment of the U.S. Audit Market." The Accounting Review (January): 145-157.

11. G. Benston. 1979-80. "The Market for Public Accounting Services: Demand, Supply and Regulation." The Accounting Journal (Winter): 2-46.

12. Standard and Poor's Register of Corporations, Directors, and Executives, Vols. 1 and 3. 1985. New York: Standard and Poor's Corporation.

13. S. Harris. Who Audits America. 1985. Menlo Park, Calif.: Data Financial Press.

14. L. De Angelo. 1981. "Auditor Independence, 'Low Balling,' and Disclosure Regulation." Journal of Accounting and Economics (August): 113-127.

15. A. M. Oppenheim. 1966. Questionnaire Design and Attitude Measurement. New York: Harper Books.

16. S. Goldfeld and R. Quandt. 1965. "Some Tests for Homoscedasticity." Journal of the American Statistical Association (June): 539-547.

17. J. Neter, W. Wasserman, and M. Kutner. 1983. Applied Linear Regression Models. Homewood, Ill.: Richard D. Irwin. 